\title{
A METHOD FOR THE EVALUATION OF HYPNOTICS IN MAN
}

\author{
D. Jackson, M.D., P. G. Gooding, M.B., B.S., \\ Clinical Research Dcpartment, Pfizer Ltd, Sandwich, Kent
}

IN THIS study, the principle of using a physiological fluid load to produce a disturbance in the sleep of normal subjects has been utilized both for the evaluation of the non-barbiturate hypnotic, ethchlorvynol ('Arvynol': Pfizer) and to compare its hypnotic effect with glutethimide ('Doriden': Ciba). The technique, which is based on the work of Isaacs (1957 a,b.) and Condouris, Costa and Bonnycastle (I960), has been adapted to provide a simple reproducible method for evaluating and comparing hypnotics in man.

Ethchlorvynol, ethyl- $\beta$-chlorovinyl ethinyl carbinol, has been shown to produce hypnotic effects in animals (P'An, Kodet, Gardocki, McLamore and Bavley, 1955) and to be as effective as glutethimide (Cuthbert, 1963) thalidomide, butobarbitone (Woodd-Walker, I963) and dichloralphenazone (Tsapogas, Modle \& Wheeler, 1962) in clinical trial. In addition, when compared with an equivalent dose of thalidomide in rabbits, ethchlorvynol produced no teratogenic effects whereas thalidomide in the same experiment produced either stillbirth or teratogenic effects in the great majority of the offspring (Reinert, 1962). No effect on the human fætus has been noted in the U.S.A. where this hypnotic has been available for over 6 years.

\section{Methods}

This study was carried out in four phases on healthy adult subjects of both sexes with no history of insomnia or recent disease.

In the first phase each subject was given one of five treatments on each of five different nights in a randomized order. These treatments were a placebo, $250 \mathrm{mg}$. glutethimide, $500 \mathrm{mg}$. glutethimide, 200mg. ethchlorvynol and $500 \mathrm{mg}$. ethchlorvynol. Each subject was instructed to take the hypnotic and a water load ( $\mathrm{I} \frac{1}{2}$ pints) on retiring and note this time and the time of first waking. However, after the first night of the experiment it became apparent that $\mathrm{I} \frac{1}{2}$ pints of water produced a disturbance of sleep irrespective of whether the subjects received either a hypnotic or a placebo. Therefore, for the following four nights the water load was reduced to $\frac{3}{4}$ pint but this amount was later found to be inadequate.

Further experiments (phase 2) demonstrated that I pint of milk produced a more consistent disturbing effect on sleep. In our experience the majority of subjects prefer milk to water and the use of a one-pint bottle ensures the correct volume being taken.
In phase 3 ethchlorvynol was compared with a placebo and in the final phase with both glutethimide and a placebo.

\section{Results}

The results of the water-load experiment can be seen in Table $I$, which shows the mean sleeping time obtained following a $1 \frac{1}{2}$-pint water loa㧨 (ist night only); a $\frac{3}{4}$-pint water load (nights 2-\$o inclusive); and the effects over all five nights. Iro this phase, 7I subjects participated.

As these preliminary trials demonstrated that the technique in this form was not suitable for oup purpose phase 2 was carried out as a small pilot. review, with six subjects only (all males) with an intermediate fluid load of I pint of milk. Thịi second investigation was organized as a cross-o trial on two nights only with a placebo and 500 rigo ethchlorvynol. The results (Table 2) show difference between sleeping times for the hypnotie and placebo which suggested that this modifiec procedure was more suitable and that with large numbers, statistically valid results could be obtained.

Phase 3 was organized as a cross-over study with $500 \mathrm{mg}$. ethchlorvynol and a placebo in 24 subjects. (12 male and 12 female). On the first night half of each group received the placebo and the other half the active tablet, the alternate treatment being given on the second night. It was also decided to take the difference in time between retiring to beक and actually getting up to empty the bladder rather than the time of first waking, since previous experience had shown that some subjects were minimally roused but did not get out of bed. The results of the phase and a combined analysis of sleeping times for phases 2 and 3 together, are shown in Table 3. A further analysis demonstrate象 that the average duration of sleep on the second ${ }^{\omega}$ night both with the hypnotic and with the placebos? was significantly longer than on the first night. can also be seen that irrespective of night of treatment, females had a significantly longet sleeping time than males (Table 4).

Utilizing the experience and results obtaine from the first three phases of this investigation, the्ष 
TABLE I

Phase I: Water I.oAd Experiments

\begin{tabular}{|c|c|c|c|c|c|c|}
\hline \multirow{2}{*}{$\begin{array}{c}\text { No. of subjects: } 7 \mathrm{I} \\
\text { Treatment }\end{array}$} & \multicolumn{2}{|c|}{$\begin{array}{c}\text { Ist night only } \\
\text { (I } \frac{1}{2} \text {-pint water load) }\end{array}$} & \multicolumn{2}{|c|}{$\begin{array}{l}\text { Nights } 2-5 \text { inclusive } \\
\text { (3-pint Water load) }\end{array}$} & \multicolumn{2}{|c|}{ Over all five nights } \\
\hline & $\begin{array}{l}\text { Mean } \\
\text { sleeping time } \\
\text { hrs. mins. }\end{array}$ & $\begin{array}{l}\text { Difference } \\
\text { mins. }\end{array}$ & $\begin{array}{l}\text { Mean } \\
\text { sleeping time } \\
\text { hrs. mins. }\end{array}$ & $\begin{array}{l}\text { Difference } \\
\text { mins. }\end{array}$ & $\begin{array}{l}\text { Mean } \\
\text { sleeping time } \\
\text { hrs. mins. }\end{array}$ & $\begin{array}{l}\text { Difference } \\
\text { mins. }\end{array}$ \\
\hline $\begin{array}{l}\text { Placebo } \\
\text { 2. } 250 \mathrm{mgm} \text {. glutethimide } \\
\text { 3. } 500 \mathrm{mgm} \text {. glutethimide } \\
\text { t. } 200 \mathrm{mgm} \text {. ethchlorvynol } \\
\text { 5. } 500 \mathrm{mgm} \text {. ethchlorvynol }\end{array}$ & $\begin{array}{ll}4 & 46 \\
4 & 46 \\
4 & 57 \\
4 & 49 \\
5 & 21\end{array}$ & $\begin{array}{l}- \\
+11 \\
+3 \\
+35\end{array}$ & $\begin{array}{rr}6 & 18 \\
6 & 11 \\
6 & 27 \\
6 & 6 \\
6 & 23\end{array}$ & $\begin{array}{l}- \\
-7 \\
+9 \\
-12 \\
+\quad 5\end{array}$ & $\begin{array}{rr}6 & 3 \\
5 & 58 \\
6 & 7 \\
5 & 52 \\
6 & 12\end{array}$ & $\begin{array}{l}- \\
-5 \\
+4 \\
-11 \\
+9\end{array}$ \\
\hline significant difference $(P=.05)$ & & 127 & & $4 I$ & & 40 \\
\hline
\end{tabular}

TABLE 2

Phase 2: Cross Over Study with 6 Subjects for 2 Nights

\begin{tabular}{l|rc}
\hline \multicolumn{1}{c|}{ Treatment } & $\begin{array}{r}\text { Mean sleeping time } \\
\text { hrs. }\end{array}$ & mins. \\
\hline 500 mgm. ethchlorvynol & 6 & 50 \\
Placebo & 4 & 37 \\
\hline Difference & 2 & 13 \\
\hline Significant difference $(\mathrm{P}=.05)$ & 2 & $5 \mathrm{I}$ \\
\hline
\end{tabular}

TABLE 3

Phase 3: Cross Over Study with Hypnotic and Placebo

\begin{tabular}{|c|c|c|}
\hline & $\begin{array}{l}24 \text { subjects: } \\
\text { phase } 3 \text { only }\end{array}$ & $\begin{array}{c}30 \text { subjects: } \\
\text { phases } 2 \text { and } 3\end{array}$ \\
\hline Treatment & $\begin{array}{l}\text { Mean } \\
\text { sleeping time } \\
\text { hrs. mins. }\end{array}$ & $\begin{array}{l}\text { Mean } \\
\text { sleeping time } \\
\text { hrs. mins. }\end{array}$ \\
\hline $\begin{array}{l}500 \mathrm{mgm} \text {. ethchlorvynol } \\
\text { Placebo }\end{array}$ & $\begin{array}{ll}7 & 23 \\
6 & 30\end{array}$ & $\begin{array}{rr}7 & 16 \\
6 & 8\end{array}$ \\
\hline Difference & $53^{*}$ & $8^{*}$ \\
\hline $\begin{array}{l}\text { Significant difference } \\
(\mathrm{P}==.05)\end{array}$ & 50 & 47 \\
\hline
\end{tabular}

*These differences are significant

final experiment was carried out as follows: 60 volunteer subjects were given a one-pint fluid load in the form of milk together with a placebo on retiring. The time at which they retired was noted and also the time at which they were sufficiently disturbed to get up and empty their bladders. From this information 30 subjects were selected who were obviously disturbed by this fluid load: the remaining 30 did not show any appreciable effect.
TABLE 4

Phase 3: Analysis of Order of Treatment and Sex DifFERENCE

\begin{tabular}{|c|c|c|c|c|c|}
\hline $\begin{array}{r}\text { No of subjects: } \\
24\end{array}$ & $\begin{array}{l}\text { M } \\
\text { sleep } \\
\text { hrs. }\end{array}$ & $\begin{array}{l}\text { ean } \\
\text { ng time } \\
\text { mins. }\end{array}$ & & $\begin{array}{l}\text { M } \\
\text { sleepi } \\
\text { hrs. }\end{array}$ & $\begin{array}{l}\text { ean } \\
\text { ig time } \\
\text { mins. }\end{array}$ \\
\hline $\begin{array}{l}\text { Ist night } \\
\text { 2nd night }\end{array}$ & $\begin{array}{l}6 \\
7\end{array}$ & $\begin{array}{l}31 \\
22\end{array}$ & $\begin{array}{l}\text { Males } \\
\text { Females }\end{array}$ & $\begin{array}{l}6 \\
7\end{array}$ & $\begin{array}{r}3 \\
50\end{array}$ \\
\hline Difference & & $5^{1 *}$ & & $\mathbf{I}$ & $47^{*}$ \\
\hline $\begin{array}{l}\text { Significant dif- } \\
\text { ference }(P= \\
\text {.05) }\end{array}$ & & 50 & & & 50 \\
\hline
\end{tabular}

* These differences are significant

TABLE 5

Phase 4: 30 Subjects in a 3-Night Cross-Over Study

\begin{tabular}{|c|c|c|c|c|}
\hline \multirow[b]{2}{*}{$\begin{array}{l}\text { Placebo } \\
500 \text { mgm. ethchlorvynol } \\
500 \text { mgm. glutethimide }\end{array}$} & \multicolumn{2}{|c|}{$\begin{array}{l}\text { Mean } \\
\text { sleeping time } \\
\text { hrs. mins. }\end{array}$} & \multicolumn{2}{|c|}{$\begin{array}{l}\text { Difference } \\
\text { hrs. mins. }\end{array}$} \\
\hline & $\begin{array}{l}5 \\
6 \\
6\end{array}$ & $\begin{array}{l}21 \\
43 \\
52\end{array}$ & $\begin{array}{l}\mathbf{I} \\
\mathbf{I}\end{array}$ & $\begin{array}{l}22^{*} \\
3 I^{*}\end{array}$ \\
\hline $\begin{array}{l}\text { Significant difference } \\
(\mathrm{P}=.05)\end{array}$ & & & I & 5 \\
\hline
\end{tabular}

The 30 subjects selected for further study were then given one of three treatments together with a pint of milk at night in a random order. These treatments were a placebo, $500 \mathrm{mg}$. ethchlorvynol and $500 \mathrm{mg}$. glutethimide. On the second and third nights they received the other treatments. The results (Table 5) deomonstrate that ethchlorvynol $500 \mathrm{mg}$. and glutethimide $500 \mathrm{mg}$. have an equal hypnotic action which is significantly greater than that of the placebo. 
Side effects were encountered on only a small proportion of subjects (ethchlorvynol 10\%: glutethimide $13 \%$ : placebo $7 \%$ ), and consisted of slight headache or dry mouth on wakening. There was no significant difference between the incidence of these side effects with ethchlorvynol, glutethimide or the placebo. This compares with the findings of Goldstein (1953). Similarly drowsiness of a transient nature was noted in some subjects, but again occurred in the same proportion of each group.

\section{Discussion}

The experience and results obtained from the early phases of this investigation led to the final experiment which showed that both glutethimide and ethchlorvynol produce the same hypnotic effect at a dose of $500 \mathrm{mg}$. In addition, both produce a statistically significant increase in sleeping time when compared with a placebo. Side effects were minimal and there was no difference between the incidence with ethchlorvynol, glutethimide or the placebo.

The method which we finally evolved is simple to operate and causes less inconvenience to the subjects than similar techniques which necessitate urine collection. In addition, it gives reproducible results and allows a comparison to be made between the duration of action of different hypnotics.

In the original work by Isaacs, (1957 b.) all subjects were asked to collect and measure the urine passed on waking. Within certain limits it was suggested that the depth of sleep could be estimated from the product of the log of the sleeping time and the log of the urine volume passed on first waking. However, this scheme has two drawbacks; first, there is no clear correlation between volume of urine voided and the duration of sleep (Condouris and others 1960) and, second, subjects often do not complete the course of an experiment, if it requires the collection and measurement of urine. Indeed, Isaacs (1957 b.) found that of 109 students in his investigation only 9 submitted a complete record. In contrast, by employing our modified technique we obtained complete returns from I 3 I subjects out of a total of I5O.

The results of the water-load experiments did not show statistically significant differences between hypnotic and placebo. We consider there are two reasons for this finding which were overcome by modifying the technique. There are many people who are unaffected by the fluid-load stimulation irrespective of whether they receive a hypnotic or a placebo. Since disturbance of sleep is the basis of this technique all subjects were given a placebo on the first night, and it was noticed whether or not the fluid-load stimulation disturbedo sleep. Approximately half can be described as 'fluid load responders' and this agrees with theo findings of Condouris and Bonnycastle (196r) Only these selected subjects in whom sleep was disturbed were then included in the remainder off the experiment. In the initial experiments a water? load of either $1 \frac{1}{2}$ pints or $\frac{3}{4}$ pint was used. The larger volume produced sleep disturbance in nearly all subjects, irrespective of whether they had received a hypnotic or a placebo, but the smalleren volume proved inadequate. Further work demonstrated that the ideal compromise was a pint of milk: which the subjects found more palatable, and in addition this enabled the exact volume of fluid tog be taken on each occasion.

Further analysis of the earlier experiments. employing a water load showed a statistically $\overrightarrow{0}$ significant difference between the first and second nights, the second night showing an increase im sleeping time irrespective of treatment. This was found also by Condouris and others (1960). To overcome this, all subjects were given, unknown to음 them, a placebo on the first night of the study, as well as a placebo during the trial, in a random order with the test hypnotics. It is considered that this difference is an exaggerated placeboo response in subjects many of whom were takingrap hypnotic for the first time.

Our studies showed that, again irrespective 에의 treatment, females slept longer than males, and thedifference was statistically significant. This is in direct contrast to the findings of Lasagna (1954) who found that males slept longer than females None of the males in our series had symptoms of prostatic enlargement and we are unable to explain? this difference between the sexes.

The quality of the sleep cannot readily be determined with this technique as the only means of analysis is a subjective assessment the next day It is felt that quality can best be estimated from trials in hospital patients who can be observed? during sleep, (Cuthbert, I963). However, aş assessed subjectively in our series, no differenceso could be detected between the quality of sleep following ethchlorvynol, glutethimide or a placebo을

The evaluation of hypnotics by this methoo does presume that the test compounds have no diuretic action. In our experience this modified technique is a useful and reproducible method fot the comparative evaluation of hypnotics and, ing particular, their duration of action. Furthermore the duration of hypnotic effect found in these experiments correlates with that observed in? patients (Cuthbert, 1963).

\section{Summary}

A technique is described for the evaluation and 
comparison of hypnotics in normal subjects. This method employs a physiological fluid load to produce a disturbance of sleep, the hypnotic effect being measured as the duration of sleep between retiring and waking to empty the bladder.

Using this technique ethchlorvynol $500 \mathrm{mg}$. and glutethimide $500 \mathrm{mg}$. were found to produce a comparable hypnotic effect and the duration of sleep was comparable to that produced by the same dose of these hypnotics in hospital patients.

We would like to thank the Board of Pfizer Ltd., for permission to undertake this investigation, and wish to acknowledge the invaluable help of Sister Beadman, the staff of the Medical Room, the members of the Clinical Research Department, the subjects who participated in this study, and Mr. P. R. D. Avis for help with the statistical analysis.

\section{REFERENCES}

Condouris, G. A., Bonnycastle, D. D. (r96r): A Pharmacological Investigation of the Hypnotic Action of a New Derivative of Chloral Hydrate, Chlorhexadol, Amer. F. med. Sci., 242, 574.

- - Costa, P. J., Bonnycastle, D. D. (1960): A Study of Hynpotics in Normal Subjects with Induced Awakening, Clin. Pharmacol. Ther., I, 454.

Cuthbert, K. J. R. (1963): A Clinical Comparison of Two Hypnotics, Practitioner, r9o, 509.

Goldstein, A. (1953): A Pharmacological Teaching Exercise with Barbiturates, ₹. med. Educ., $28,48$.

IsAacs, B. (1957): Method for Evaluation of Hypnotic Drugs, Lancet, $\mathbf{i}, 556$.

- (1957): Hypnotic Effect of Glutethimide in Normal Human Subjects, ibid., i, $55^{8}$.

Lasagna, L. (r954): A Comparison of Hypnotic Agents, $\mathcal{F}$. Pharmacol. exp. Ther. Iir, 9.

P'AN, S. Y., Kodet, M. J., Gardocki, J. F., McLamore, W. M., and Bavley, A. (I955): Pharmacological Studies on the Hypnotic and Anticonvulsant Actions of Ethyl Beta-Chlorovinyl Ethynyl Carbinol, ibid., 14r, 326.

Reinert H. (r962): Personal Communication.

Tsapogas, M. J. C., Modle, J., Wheeler, T. (1963): A Comparison between Two Hypnotics Ethchlorvynol and Dichloral-Phenazone (Welldorm), Brit. F. clin. Pract., 17, 407.

Woodd-Walker, R. B., (1963): A Clinical Evaluation of a Non-Barbiturate Hypnotic, Ethchlorvynol, Brit. F. clin. Pract., 17,201. 